\title{
Comparison of laparoscopic sleeve gastrectomy leak rates in five staple-line reinforcement options: a systematic review
}

\author{
Michel Gagner ${ }^{1,2,3}$. Paul Kemmeter ${ }^{4}$
}

Received: 10 December 2018 / Accepted: 4 April 2019 / Published online: 16 April 2019

(c) The Author(s) 2019

\begin{abstract}
Background Staple-line leaks following laparoscopic sleeve gastrectomy (LSG) remain a concerning complication. Stapleline buttressing is largely adopted as an acceptable reinforcement but data regarding leaks have been equivocal. This study compared staple-line leaks in five reinforcement options during LSG: no reinforcement (NO-SLR), oversewing (suture), nonabsorbable bovine pericardial strips (BPS), tissue sealant or fibrin glue (Seal), or absorbable polymer membrane (APM). Methods This systematic review study of articles published between 2012 and 2016 regarding LSG leak rates aligned with the Preferred Reporting Items for Systematic Reviews and Meta-Analyses guidelines. Variables of interest included leak rates, bleeding, and complications in addition to surgical and population parameters. An independent Fisher's exact test was used to compare the number of patients with and without leaks for the different reinforcement options.

Results Of the 1633 articles identified, 148 met inclusion criteria and represented 40,653 patients. Differences in age (older in APM; $p=0.001$ ), starting body mass index (lower in Suture; $p=0.008$ ), and distance from pylorus (closer in BPS; $p=0.04$ ) were observed between groups, but mean bougie size was equivalent. The overall leak rate of $1.5 \%$ (607 leaks) ranged from $0.7 \%$ for APM (significantly lower than all groups; $p \leq 0.007$ for next lowest leak rate) to $2.7 \%$ (BPS).

Conclusions This systematic review of staple-line leaks following LSG demonstrated a significantly lower rate using APM staple-line reinforcement as compared to oversewing, use of sealants, BPS reinforcement, or no reinforcement. Variation in surgical technique may also contribute to leak rates.
\end{abstract}

Keywords Bariatric $\cdot$ Metabolic $\cdot$ Laparoscopic sleeve gastrectomy $\cdot$ LSG $\cdot$ Leak $\cdot$ Staple line $\cdot$ Reinforcement $\cdot$ Systematic review

An abstract based on these data were accepted for oral presentation at Obesity Week 2018; November 11-15, 2018, Nashville,

Tennessee, USA, in association with the American Society for Metabolic and Bariatric Surgery and the Obesity Society.

Electronic supplementary material The online version of this article (https://doi.org/10.1007/s00464-019-06782-2) contains supplementary material, which is available to authorized users.

Michel Gagner

gagner.michel@gmail.com

Paul Kemmeter

pkemmeter@grandhealthpartners.com

1 Department of Surgery, Hopital du Sacré Coeur, 315 Place D'Youville, Suite 191, Montréal, QC H2Y 0A4, Canada

2 Herbert Wertheim School of Medicine, Florida International University, Miami, FL, USA

3 Westmount Square Surgical Center, Westmount, QC, Canada

4 Department of Surgery, Mercy Health Saint Mary's, 2060 E Paris Ave SE \#100, Grand Rapids, MI, USA
Laparoscopic sleeve gastrectomy (LSG) has become the most commonly performed primary bariatric procedure performed in the United States (US) and worldwide [1, 2]. Since its early days of adoption, the complication of stapleline leak remains the greatest concern with the reported leak rates averaging $2.4 \%$ and ranging from 1.1 to $4.7 \%$ [3-8]. Over the past 10 years, multiple studies have attempted to identify parameters associated with decreasing the risk of leaks, which have included: varying bougie size, distance from the pylorus, surgeon experience, and reinforcement of the staple line [6, 9-12]. In regards to staple-line reinforcement, expert opinion from the International Sleeve Gastrectomy Consensus Conference in 2011 demonstrated that $77 \%$ of experienced LSG surgeons deemed staple-line buttressing as "acceptable" [7]. Multiple retrospective studies have further evaluated staple-line reinforcement, with the largest study published to date utilizing the Metabolic and Bariatric Surgery Accreditation Quality Improvement Program 
data base [10]. This study suggested that reinforcement of the staple line may actually be associated with increased leak rates, but the study results were limited by the lack of granular data to separate outcomes based on actual type of reinforcement utilized and the inclusion of discontinued material (i.e. glycolide diaxonone trimethylene carbonate, Duet TRS, Covidien, Norwalk, CT) [10].

In an attempt to provide buttressing-specific data, we previously reported the results of a systematic review of 88 articles published up to March 2012 with the purpose of comparing staple-line leak rates of 4 prevalent surgical staple-line reinforcement methods in 8279 LSG procedures. In that review, the overall leak rate was $2.1 \%$, with the lowest rate in absorbable permeable membrane (APM) reinforced staple lines of $1.09 \%$ [13]. Our follow-up to this study included an additional 3416 APM-reinforced LSG patients and demonstrated that overall leak rates decreased to $0.67 \%$ from 2012 to 2015, perhaps suggesting a "learning curve" associated with the procedure [14].

Since the cutoff date for these previous reviews, the use of tissue sealants has become more prevalent. In this current systematic review, relevant articles of LSG and the use of staple-line reinforcement methods published from 2012 to 2016 are evaluated. The leak rates from 5 reinforcement methods of no reinforcement (NO-SLR), over sewing (Suture), bovine pericardium membrane (BPM), tissue sealant (Seal), and APM are evaluated.

\section{Methods and materials}

\section{Search strategy, inclusion criteria, variables of interest}

The search strategy used for this current review was consistent with our systematic review reported in 2014 and was aligned with the Preferred Reporting Items for Systematic Reviews and Meta-Analyses statement (PRISMA) [13, 15]. Briefly, the electronic literature search of the BIOSIS Previews ${ }^{\circledR}$, Embase ${ }^{\circledR}$, Embase ${ }^{\circledR}$ Alert, and MEDLINE ${ }^{\circledR}$ databases with the keywords: "sleeve gastrectomy," laparoscopic sleeve gastrectomy," "vertical gastrectomy," "leak," "complication," "morbidity," or "fistula" limited to human patients and reports in English. The search period started from March 2012 through June 2016 (published or e-published ahead of print). Electronic results were screened by title to exclude duplicate studies and the remaining records were screened by reading abstracts. Full-text articles were included only if an LSG procedure, leak data, and type of staple-line reinforcement were reported. Of note, articles may have reported data for more than 1 reinforcement method of interest. As summarized in Fig. 1, excluded from eligibility were: Comments, Letters to the Editor, case reports series or studies with sample sizes of $\leq 5$ patients, animal studies, review articles without accompanying data, and kin studies (i.e., reports with overlapping data or an author group that reported outcomes for similar periods of time). Analysis objectives centered on 5 reinforcement methods NO-SLR, suture, BPM, tissue sealant seal, APM and the number of patients with leak and without leak; bleeding, overall complications, and mortality were collected as text fields but not categorically summarized. Additionally, population and surgical variables of gender, age, body mass index (BMI), calibrating bougie size, and distance between the pylorus and gastric transection line were collected. Stapler types, staple heights, port type, number and placement, and other procedural characteristics were not included, as these details were not consistently reported.

\section{Abbreviated terms}

No reinforcement $=$ "NO-SLR". Reinforcement by over sewing alone $=$ "suture". Reinforcement with nonabsorbable bovine pericardial strips (Peri-Strips Dry, Baxter ${ }^{\circledR}$ Healthcare, St. Paul, MN) = "BPS". Reinforcement with tissue sealant or fibrin glue (FloSeal or Tisseel fibrin sealant [Baxter ${ }^{\circledR}$ Deerfield, IL, USA], Ifabond ${ }^{\circledR}$ glue [Ifamedical, France], or Evicel $^{\circledR}$ glue [Ethicon ${ }^{\mathrm{TM}}$ Biosurgery, Inc., Somerville, NJ, USA] = "Seal". Reinforcement with absorbable polymer membrane $\left(\right.$ GORE $^{\circledR}$ SEAMGUARD $^{\circledR}$, W. L. Gore \& Associates, Elkton, MD, USA) = "APM".

\section{Statistical analysis}

Data were extracted by an individual from original sources to fields within an Excel (Microsoft, Redmond, WA, USA) database. Data manipulation and analysis was conducted using JMP statistical software, version 13.2.0 (SAS Institute Inc., Cary, NC). Criteria-based data were aggregated from selected studies representative of the 5 LSG reinforcement options of interest. Select demographic variables of age, $\%$ females, and body mass index (BMI, $\mathrm{kg} / \mathrm{m}^{2}$ ) and the surgical technique variables of bougie size and distance from pylorus were summarized using mean, standard deviation, range, and the percentage of studies reporting on each variable. The overall leak rate for LSG patients, as well as, patient leak rates within each of the 5 reinforcement categories were calculated. An independent Fisher's exact tests was used to compare the number of patients with and without leaks for the different reinforcement options [16]. All statistical tests were 2-tailed and alpha was set at $p<0.05$. 


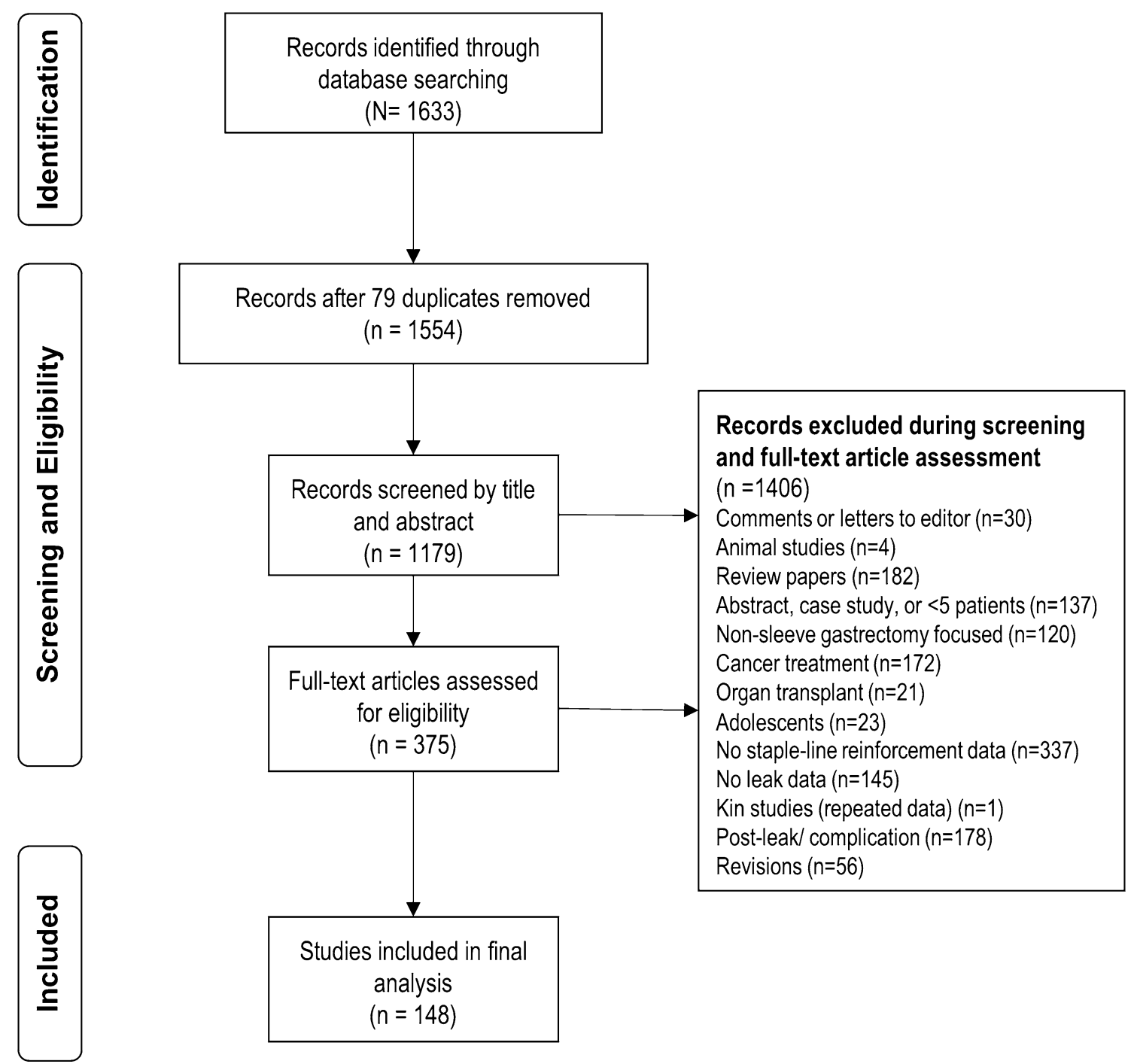

Fig. 1 Search strategy

\section{Results}

\section{Study characteristics}

A total of 1633 articles were identified in the initial search. Figure 1 illustrates the identification, screening, and eligibility selection process. After removing duplicates $(n=79)$, the 1554 records were screened by title and abstract after which 1179 were excluded and the full-text articles for the remaining 375 records were assessed for eligibility. A total of 148 papers were included in the final analysis and the number of studies per reinforcement method were: 69 for NO-SLR $[9,17-84], 70$ for suture $[9,19,20,22,26,30,46,51,53$, $75,76,78,83,85-140], 9$ for BPS $[9,72,78,83,86,89$, 141-143], 9 for Seal $[9,30,61,74,78,103,144-146]$, and 24 for APM [9, 39, 52, 53, 63, 89, 103, 131, 147-162]. Studies included in the analysis were comprised of 11 case series,
22 prospective randomized studies, 29 prospective studies, 1 randomized clinical trial, and 85 retrospective reviews and were conducted in Western Europe $(n=58)$, the US $(n=33)$, and other regions ( $n=57$; i.e. Asia and Middle East). Table 1 describes the study characteristics by reinforcement method and the associated article reference which reflects "doublecounting" of an article in cases when more than 1 reinforcement method was reported for an article.

\section{Patient characteristics}

The final analysis consisted of 40,653 patients from the 148 papers. At least one of the three patient characteristics variables (age, gender, or starting BMI) were reported in all but the following eight studies representing 12,473 patients [24, 28, 49, 63, 76, 97, 144]. In 8 additional studies, only one of the three patient characteristic variables 
Table 1 Characteristics of accepted studies by reinforcement method groups

\begin{tabular}{|c|c|c|c|c|c|}
\hline & \multicolumn{5}{|c|}{ Reinforcement method } \\
\hline & NO-SLR & Suture & BPS & Seal & APM \\
\hline \multicolumn{6}{|l|}{ Variables } \\
\hline Publication date range & 2012-2016 & 2012-2016 & 2012-2015 & 2012-2015 & $2012-2016$ \\
\hline \multicolumn{6}{|l|}{ Study design type ${ }^{a}$} \\
\hline Case series & 2 & 7 & 2 & 1 & 2 \\
\hline Prospective randomized & 13 & 12 & 2 & 4 & 1 \\
\hline Prospective & 11 & 17 & 1 & 2 & 5 \\
\hline Randomized clinical trial & 0 & 1 & 0 & 0 & 0 \\
\hline Retrospective review & 43 & 33 & 4 & 2 & 16 \\
\hline Total & $\mathrm{N}=69$ & $\mathrm{~N}=70$ & $\mathrm{~N}=9$ & $\mathrm{~N}=9$ & $\mathrm{~N}=24$ \\
\hline \multicolumn{6}{|l|}{ Region, $\mathrm{n}(\%)^{\mathrm{a}}$} \\
\hline Other & $26(36.1)$ & $38(52.8)$ & $4(0.06)$ & $3(0.46)$ & $1(0.01)$ \\
\hline United States & $10(27.0)$ & $15(40.5)$ & $1(0.03)$ & $1(0.03)$ & $10(27.0)$ \\
\hline Western Europe & $33(45.8)$ & $17(23.6)$ & $4(0.06)$ & $5(0.07)$ & $13(18.1)$ \\
\hline
\end{tabular}

$A P M$ absorbable polymer membrane, BPS bovine pericardial strips, $N O$-SLR no staple-line reinforcement, $n$ number of studies per reinforcement type, $N$ number of studies overall, $N R$ not reported, $P$ prospective, $R$ retrospective, $R C T$ randomized controlled trial, seal tissue sealant, suture oversewing alone

${ }^{a} \mathrm{~N}=148$ for total number of citations included in analysis and $\mathrm{N}=181$ for total reinforcement outcome results and reflects some articles that were double counted for report of more than 1 reinforcement method were reported. Age was not reported for 40 patients in one study [43]; gender was missing for 1103 patients in 5 studies $[42,52,143,159,161]$; and starting BMI was not reported for 45 patients in two studies [25, 162]. Overall, patients had a mean age of 41 years, a mean starting BMI of $46.1 \mathrm{~kg} / \mathrm{m}^{2}$, and $74 \%$ were female. Among studies reporting characteristics, differences were noted among the five reinforcement method groups in that patients in the APM group were older $\left(45.6 \pm 3.2 \mathrm{~kg} / \mathrm{m}^{2}\right.$; $p=0.001)$ and the starting BMI was lower for the suture group $\left(43.7 \pm 4.3 \mathrm{~kg} / \mathrm{m}^{2} ; p=0.008\right)$. The gender ratio in this analysis data set was similar across the reinforcement groups (Table 2).

\section{Surgical technique}

The mean bougie size ranged from $36 \mathrm{Fr}$ (NO-SLR and suture groups) to $34.6 \mathrm{Fr}$ (Seal group); the differences between reinforcement type groups were not significantly different. The mean distance from pylorus ranged from $3.2 \mathrm{~cm}$ (BPS group) to $5.0 \mathrm{~cm}$ (suture group) and the difference was significantly different $(p=0.04)$ (Table 3$)$.

\section{Staple-line leak rate}

A total of 607 leaks were reported in 40,653 patients yielding an overall leak rate of $1.49 \%$ (Table 4 ). The percentage

Table 2 Characteristics of patients reported in accepted studies by reinforcement method

\begin{tabular}{|c|c|c|c|c|c|c|}
\hline & \multicolumn{5}{|c|}{ Reinforcement method } & \multirow[t]{2}{*}{$p$ value } \\
\hline & NO-SLR & Suture & BPS & Seal & APM & \\
\hline \multicolumn{7}{|c|}{ Variables mean $\pm \mathrm{SD}\left(\right.$ range $\left.^{\mathrm{a}}\right)\left[\%\right.$ reported $\left.^{\mathrm{b}}\right]$} \\
\hline Age, years & $\begin{array}{c}39.9 \pm 5.2(29.9- \\
54.3)[90 \%]\end{array}$ & $\begin{array}{l}41.1 \pm 5.4(27.0- \\
64.1)[96 \%]\end{array}$ & $\begin{array}{c}38.6 \pm 5.5(31.5- \\
45.6)[100 \%]\end{array}$ & $\begin{array}{c}39.8 \pm 3.9(32.3- \\
44.1)[89 \%]\end{array}$ & $\begin{array}{c}45.6 \pm 3.2(41.0- \\
54.5)[92 \%]\end{array}$ & 0.0009 \\
\hline Female, $\%$ & $\begin{array}{c}75.9 \pm 8.8(47.0- \\
100.0)[88 \%]\end{array}$ & $\begin{array}{c}75.2 \pm 8.6(43.0- \\
95.0)[96 \%]\end{array}$ & $\begin{array}{c}73.2 \pm 8.3(40.0- \\
86.0)[89 \%]\end{array}$ & $\begin{array}{c}71.3 \pm 14.9(39.0- \\
92.0)[89 \%]\end{array}$ & $\begin{array}{c}73.2 \pm 11.5(10.0- \\
100.0)[79 \%]\end{array}$ & 0.7608 \\
\hline $\begin{array}{l}\text { Starting BMI, } \mathrm{kg} / \\
\mathrm{m}^{2}\end{array}$ & $\begin{array}{c}44.5 \pm 4.9(32.6- \\
66.0)[90 \%]\end{array}$ & $\begin{array}{l}43.7 \pm 4.3(34.9- \\
68.4)[96 \%]\end{array}$ & $\begin{array}{c}47.0 \pm 3.4(42.0- \\
51.0)[100 \%]\end{array}$ & $\begin{array}{c}47.9 \pm 7.7(42.1- \\
65.0)[89 \%]\end{array}$ & $\begin{array}{c}47.4 \pm 3.3(40.1- \\
55.5)[88 \%]\end{array}$ & 0.0079 \\
\hline
\end{tabular}

APM absorbable polymer membrane, BPS bovine pericardial strips, $N$ number of patients, $N O$-SLR no staple-line reinforcement, seal tissue sealant, suture oversewing alone

${ }^{\mathrm{a}}$ Minimum to maximum

${ }^{\mathrm{b}}$ Percentage of studies that reported variables 
Table 3 Bougie size and distance from pylorus by reinforcement method

\begin{tabular}{|c|c|c|c|c|c|c|}
\hline & \multicolumn{5}{|l|}{ Reinforcement method } & \multirow[b]{2}{*}{$p$ value } \\
\hline & NO-SLR & Suture & BPS & Seal & APM & \\
\hline \multicolumn{7}{|c|}{ Variables mean \pm SD $\left(\right.$ range $\left.^{\mathrm{a}}\right)\left[\%\right.$ reported $\left.^{\mathrm{b}}\right]$} \\
\hline $\begin{array}{l}\text { Bougie } \\
\text { size } \\
(\mathrm{Fr})\end{array}$ & $\begin{array}{l}36.1 \pm 2.1(30.0-50.0) \\
{[97 \%]}\end{array}$ & $\begin{array}{l}36.2 \pm 7.2(27.0-60.0) \\
{[93 \%]}\end{array}$ & $\begin{array}{l}35.1 \pm 3.1(32.0-40.0) \\
{[89 \%]}\end{array}$ & $\begin{array}{l}34.6 \pm 4.7(26.4-40.0) \\
{[78 \%]}\end{array}$ & $\begin{array}{l}35.7 \pm 2.4(29.0-42.0) \\
\quad[92 \%]\end{array}$ & 0.9834 \\
\hline $\begin{array}{l}\text { Distance } \\
\text { from } \\
\text { pylorus } \\
\text { (cm) }\end{array}$ & $\begin{array}{l}4.8 \pm 1.1(1.5-6.5) \\
\quad[90 \%]\end{array}$ & $\begin{array}{l}5.0 \pm 1.6(1.5-10.5) \\
{[89 \%]}\end{array}$ & $\begin{array}{l}3.2 \pm 0.4(3.0-4.0) \\
\quad[67 \%]\end{array}$ & $\begin{array}{l}3.9 \pm 1.1(3.0-5.5) \\
\quad[67 \%]\end{array}$ & $\begin{array}{l}4.8 \pm 0.8(3.0-6.0) \\
\quad[79 \%]\end{array}$ & 0.0362 \\
\hline
\end{tabular}

$A P M$ absorbable polymer membrane, $B P S$ bovine pericardial strips, $\max$ maximum, $\min$ minimum, $N$ number of studies reporting variables, $N O$ $S L R$ no staple-line reinforcement, seal tissue sealant, suture oversewing alone

${ }^{a}$ Minimum to maximum

${ }^{b}$ Percentage of studies that reported variables

Table 4 Leak rate by reinforcement method

\begin{tabular}{lllllll}
\hline & \multicolumn{2}{l}{ Reinforcement Type } & & \\
\cline { 2 - 5 } & NO-SLR & Suture & BPS & Seal & APM & $\begin{array}{l}\text { TOTAL } \\
N=40,653\end{array}$ \\
\hline $\begin{array}{llllll}\text { Study overall } \\
\text { Leaks, } n\end{array}$ & & & & & & \\
Patients without leaks, $n$ & 16,318 & 18,092 & 1210 & 356 & 4070 & 40,046 \\
Leaks, $\%$ & 1.9 & 1.2 & 2.7 & 1.9 & 0.7 & 1.5 \\
$P$ value compared to APM & $<0.0001$ & 0.007 & $<0.0001$ & 0.0271 & - & - \\
United States only & & & & & & \\
Leaks, $n$ & 14 & 23 & 4 & 1 & 9 & \\
Patients without leaks, $n$ & 1059 & 3175 & 265 & 54 & 2302 & \\
Leaks, $\%$ & $1.30 \%$ & $0.72 \%$ & $1.49 \%$ & $1.82 \%$ & $0.39 \%$ & \\
\hline
\end{tabular}

$A P M$ absorbable polymer membrane, BPS bovine pericardial strips, $N O$-SLR no staple-line reinforcement, seal tissue sealant, suture oversewing alone

${ }^{a}$ Two-tailed Fisher's exact test

of leaks was significantly lower for the APM reinforcement method $(0.73 \%)$ compared with and in ranking order, suture (1.21\%; $p=0.007)$, NO-SLR $(1.89 \% ; p<0.0001)$, Seal $(1.89 \% ; p=0.027)$, and BPS $(2.73 \% ; p<0.0001)$ (Table 4$)$. The leak rate for the tissue sealant reinforcement method was comparable to that of no staple-line reinforcement $(p=0.271)$. When looking at only studies conducted in the US, the APM reinforcement method continues to have the lowest leak rate $(0.39 \%)$ among the reinforcement methods evaluated (Table 4).

\section{Discussion}

Laparoscopic sleeve gastrostomy is a popular operation, and in the US, LSG has surpassed Roux-en-Y gastric bypass because of more favorable outcomes of lower mortality and overall morbidity, similar weight loss, and resolution of health comorbidities at 5 years [163-166]. Further supporting LSG as a preferred procedure is the lower leak rates, the twofold lower complication rate, and a mortality rate that is half that of Roux-en-Y gastric bypass [167]. Our current meta-analysis of 148 articles gathering data on 40,653 LSG patients, demonstrates an overall leak rate of $1.5 \%$ among the 5 staple-line reinforcement methods evaluated. Reinforcement with APM had the lowest statistically significant leak rate at $0.7 \%(p \leq 0.007)$ despite a patient population that was older $(p=0.0009)$ and with a higher BMI [suture alone group had lower starting BMI $(p=0.0079)]$, both notorious as factors contributing to higher leak rates [168].

The variability in staple-line leak rates among the five reinforcement types indicates that the type of reinforcement material is an important factor related to this complication. When comparing the leak rates from the current analysis to the previous review, it is interesting to note the reliability of the data between both studies [13]. Although leak rates have 
decreased among all reinforcement types, the overall propensity is the same: APM had the lowest $(0.73 \%$ vs $1.09 \%)$ followed by suture ( $1.21 \%$ vs $2.04 \%)$, NO-SLR $(1.89 \%$ vs $2.60 \%)$, and BPS $(2.73 \%$ vs $3.30 \%)$ [13]. Though tissue sealants were not evaluated in the previous review, it should be noted in the current study that Seal and NO-SLR methods had similar leak rates and that the addition of tissue sealants in the analysis did not alter the trend of lower leak rates. We speculate that the temporal reduction in leak complications in LSG is most likely related to surgical experience since there have been minimal-to-no-changes in the buttressing material from the previous to the current review. Two studies have demonstrated that surgeon technique and skill is associated with improved outcomes following bariatric surgery [11, 169]. Improvements in surgical techniques include: improved dissection with preservation of healthier and more vascular tissue by reducing thermal injury and tissue trauma, selection of appropriate staple height to accommodate tissue thickness, avoidance of narrowing near the angularis incisura, choice of adequate bougie sizes, and avoidance of stapling along the esophagus. If this is indeed the case, there is the possibility that further reduction in leak complications could be gained by improving intraoperative strategies. It has previously been reported by the Michigan Bariatric Surgery Collaborative that more experienced and higher volume surgeons use intracorporeal suturing more frequently [11]. This trend may have occurred in this current study and resulted in lower leak rates in the suture group. Indeed, a recent randomized study comparing the use of a running suture with invagination to no reinforcement demonstrated a reduction in leak rates for the suturing approach, although this came at a cost of higher operative time by $18 \mathrm{~min}$ [170]. Increased operative time and cost with intracorporeal suturing is supported in other studies that reported an additional 13 to 24 min per case. Additionally, there is evidence that staple-line buttressing with APM may actually be more cost effective at 6-months post-surgery [39, 171]. As APM and Suture were the two reinforcements with the lowest leak rates, this comparison warrants further study.

This current review highlights that the leak rate for studies conducted in the US were lower than the overall average leak rate of all studies evaluated. The APM was associated with the lowest leak rate when looking only at studies conducted in the US $(0.39 \%)$ versus all studies in all geographic locations reported $(0.73 \%)$. Indeed, every reinforcement method had a substantially lower leak rate in the US studies compared to the overall publications, with the exception for the Seal group (1.8\% versus $1.9 \%$, respectively).

The present study had many limitations. Inherently, the nature of the review method itself is a limitation as it relies solely on data provided within the publication. Further, this systematic review included only one randomized-controlled trial that met our review criteria. The collection of granular data such as the use of reinforcement on the entire staple-line versus selective areas, the use of buttressing material on both the cartridge and anvil side versus one side or the other, stapler type, and staple height would have been beneficial. Additionally, this study did not include a discontinued variety of $100 \%$ PGA APM or a recently available variety of $100 \%$ PGA APM due to a lack of sufficient publications.

This study was not designed to evaluate costs in relation to leak or bleeding complication. It is known that leaks are extremely costly, and for example, can result in prolonged hospitalization within an intensive care unit as well as additional outpatient costs [172]. Since bleeding complications can be associated with leaks, data regarding bleeding would have been an asset. Unfortunately, these data were inconsistently reported and thus were collected as free text which could not be categorically summarized. As mentioned previously, staple height selection was not uniformly collected, but might be a significant factor associated with staple-line leaks. Thick gastric tissue (i.e. antrum) is at risk of crush injury with too short a staple load, with incomplete staple formation which would fail to close the gastric resection margin, and thin gastric tissue (i.e. cardia) is at risk of loose staple-line formation with too tall staple load. With most leaks occurring on the proximal staple line near the gastroesophageal junction, it is possible that the thinner wall is at risk of injury related to uneven staple compression or inadequate compression to approximate the tissues. Other elements may be responsible, like ischemia and morphology. Buttressing material has been shown to more evenly distribute the staple pressure over a wider surface area thus resulting in higher burst pressures and lower bleed rates [173-179]. As such, we hypothesize that the lower leak rate associated with the use of a thin buttressing material, such as APM (0.5 mm maximum total thickness), is related to improved staple compression, given, of course, appropriate staple height selection. Conversely, we speculate that the variable thicker BPS reinforcement $(0.4 \mathrm{~mm}-1.2 \mathrm{~mm})$ could result in variations of tissue compression, potentially resulting in a segment of staple line that is either too tight or too loose.

\section{Conclusion}

Systematic review of 148 included studies representing 40,653 patients found that the leak rate in LSG was significantly lower using APM staple-line reinforcement than oversewing, BPS reinforcement, or no reinforcement. Selected operative strategies can result in lower leak rates after sleeve gastrectomy. 


\section{Compliance with ethical standards}

Disclosures This study was supported by WL Gore \& Associates, more specifically for providing partial funding assistance. Dr Michel Gagner has received honoraria for speaking engagements from Medtronic, Ethicon Endo-Surgery, W.L. Gore, \& Associates and Valeant. Also, he has received research honoraria from Lexington Medical and W.L. Gore, \& Associates. Dr Paul Kemmeter has received honoraria for speaking engagements from W.L. Gore, \& Associates, and also research honoraria from W.L. Gore, \& Associates. The authors thank Ms. Millie Hollandbeck, for writing assistance, and Mr. Joshua Washburn, for biostatistical assistance.

Open Access This article is distributed under the terms of the Creative Commons Attribution 4.0 International License (http://creativeco mmons.org/licenses/by/4.0/), which permits unrestricted use, distribution, and reproduction in any medium, provided you give appropriate credit to the original author(s) and the source, provide a link to the Creative Commons license, and indicate if changes were made.

\section{References}

1. Varela JE, Nguyen NT (2015) Laparoscopic sleeve gastrectomy leads the US utilization of bariatric surgery at academic medical centers. Surg Obes Relat Dis. 11(5):987-990

2. International Federation for the Surgery of Obesity and Metabolic Disorders website; http://www.ifso.com/sleeve-gastrectom y/. Accessed 06 Mar 2018

3. Mui WL, Ng EK, Tsung BY, Lam CC, Yung MY (2008) Laparoscopic sleeve gastrectomy in ethnic obese Chinese. Obes Surg 18(12):1571-1574

4. Burgos AM, Braghetto I, Csendes A et al (2009) Gastric leak after laparoscopic-sleeve gastrectomy for obesity. Obes Surg 19(12):1672-1677

5. Csendes A, Braghetto I, León P, Burgos AM (2010) Management of leaks after laparoscopic sleeve gastrectomy in patients with obesity. J Gastrointest Surg 14(9):1343-1348

6. Aurora A, Khaitan L, Saber A (2012) Sleeve gastrectomy and the risk of leak: a systematic analysis of 4,888 patients. Surg Endosc 26(6):1509-1515

7. Rosenthal RJ, Diaz AA, Arvidsson D et al (2012) International Sleeve Gastrectomy Expert Panel Consensus Statement: best practice guidelines based on experience of $>12,000$ cases. Surg Obes Relat Dis 8(1):8-19

8. Sakran N, Goitein D, Raziel A et al (2013) Gastric leaks after sleeve gastrectomy: a multicenter experience with 2,834 patients. Surg Endosc 27(1):240-245

9. D'Ugo S, Gentileschi P, Benavoli D et al (2014) Comparative use of different techniques for leak and bleeding prevention during laparoscopic sleeve gastrectomy: a multicenter study. Surg Obes Relat Dis 10(3):450-454

10. Berger ER, Clements RH, Morton JM et al (2016) The impact of different surgical techniques on outcomes in laparoscopic sleeve gastrectomies: the first report from the Metabolic and Bariatric Surgery Accreditation and Quality Improvement Program (MBSAQIP). Ann Surg 264(3):464-473

11. Varban OA, Sheetz KH, Cassidy RB et al (2017) Evaluating the effect of operative technique on leaks after laparoscopic sleeve gastrectomy: a case-control study. Surg Obes Relat Dis 13(4):560-567
12. Cesana G, Cioffi S, Giorgia R et al (2018) Proximal leakage after laparoscopic sleeve gastrectomy: an analysis of preoperative and operative predictors on 1738 consecutive procedures. Obes Surg 28(3):627-635

13. Gagner M, Buchwald JN (2014) Comparison of laparoscopic sleeve gastrectomy leak rates in four staple-line reinforcement options: a systematic review. Surg Obes Relat Dis 10(4):713-723

14. Gagner M, Brown M (2016) Update on sleeve gastrectomy leak rate with the use of reinforcement. Obes Surg 26(1):146-150

15. Moher D, Liberati A, Tetzlaff J, Altman DG, The PRISMA Group. Preferred Reporting Items for Systematic Reviews and Meta-Analyses: The PRISMA Statement. PLoS Med 2009;6(7):e1000097

16. Agresti A (1992) A survey of exact inference for contingency tables. Statist Sci 27(1):131-153

17. Abd Ellatif ME, Abdallah E, Askar W et al (2014) Long term predictors of success after laparoscopic sleeve gastrectomy. Int J Surg 12(5):504-508

18. Abdallah E, El Nakeeb A, Youssef T et al (2014) Impact of extent of antral resection on surgical outcomes of sleeve gastrectomy for morbid obesity (a prospective randomized study). Obes Surg 24(10):1587-1594

19. Abdallah E, Emile SH, Elfeki H (2017) Laparoscopic sleeve gastrectomy with or without staple line inversion and distal fixation to the transverse mesocolon: impact on early postoperative outcomes. Obes Surg 27(2):323-329

20. Aggarwal S, Sharma AP, Ramaswamy N (2013) Outcome of laparoscopic sleeve gastrectomy with and without staple line oversewing in morbidly obese patients: a randomized study. J Laparoendosc Adv Surg Tech A 23(11):895-899

21. Al Sharqawi N, Al Sabah S, Al Mulla A, Al Anezi K, Jumaa T (2014) Conversional surgery: single-step conversion of laparoscopic adjustable gastric band to laparoscopic sleeve gastrectomy. Obes Surg 24(10):1808-1811

22. Albanopoulos K, Tsamis D, Arapaki A, Kleidi E, Zografos G, Leandros E (2015) Staple line reinforcement with stitch in laparoscopic sleeve gastrectomies. Is it useful or harmful? J Laparoendosc Adv Surg Tech A 25(7):561-565

23. Albeladi B, Bourbao-Tournois C, Huten N (2013) Short- and midterm results between laparoscopic Roux-en-Y gastric bypass and laparoscopic sleeve gastrectomy for the treatment of morbid obesity. J Obes 1:1-10. https://doi.org/10.1155/2013/934653

24. Alqahtani A, Almari H, Elahmedi M, Mohammed R (2012) Laparoscopic sleeve gastrectomy in adult and pediatric obese patients: a comparative study. Surg Endosc 26(11):3094-3100

25. Bekheit M, Katri KM, Nabil W, Sharaan MA, El Said A (2013) Earliest signs and management of leakage after bariatric surgeries: single institute experience. Alexandria J Med 49(1):29-33

26. Bellows CF, Gauthier JM, Webber LS (2014) Bariatric aftercare and outcomes in the Medicaid population following sleeve gastrectomy. JSLS. https://doi.org/10.4293/JSLS.2014.00280

27. Billing PS, Crouthamel MR, Oling S, Landerholm RW (2014) Outpatient laparoscopic sleeve gastrectomy in a free-standing ambulatory surgery center: first 250 cases. Surg Obes Relat Dis 10(1):101-115

28. Bransen J, Gilissen LP, van Rutte PW, Nienhuijs SW (2015) Costs of leaks and bleeding after sleeve gastrectomies. Obes Surg 25(10):1767-1771

29. Brockmeyer JR, Simon TE, Jacob RK, Husain F, Choi Y (2012) Upper gastrointestinal swallow study following bariatric surgery: institutional review and review of the literature. Obes Surg 22(7):1039-1043

30. Bülbüller N, Aslaner A, Oner OZ et al (2013) Comparison of four different methods in staple line reinforcement during laparascopic sleeve gastrectomy. Int J Clin Exp Med 6(10):985-990 
31. Chakravartty S, Sarma DR, Chang A, Patel AG (2016) Staple line bleeding in sleeve gastrectomy - a simple and cost-effective solution. Obes Surg 26(7):1422-1428

32. Desiderio J, Trastulli S, Scalercio V et al (2013) Effects of laparoscopic sleeve gastrectomy in patients with morbid obesity and metabolic disorders. Diabetes Technol Ther 15(12):1004-1009

33. Dogan K, Gadiot RP, Aarts EO et al (2015) Effectiveness and safety of sleeve gastrectomy, gastric bypass, and adjustable gastric banding in morbidly obese patients: a multicenter, retrospective, matched cohort study. Obes Surg 25(7):1110-1118

34. Eid GM, Brethauer S, Mattar SG, Titchner RL, Gourash W, Schauer PR (2012) Laparoscopic sleeve gastrectomy for super obese patients: forty-eight percent excess weight loss after 6 to 8 years with 93\% follow-up. Ann Surg 256(2):262-265

35. El Chaar M, Claros L, Ezeji GC, Miletics M, Stoltzfus J (2014) Improving outcome of bariatric surgery: best practices in an accredited surgical center. Obes Surg 24(7):1057-1063

36. ElGeidie A, ElHemaly M, Hamdy E, El Sorogy M, AbdelGawad M, GadElHak N (2015) The effect of residual gastric antrum size on the outcome of laparoscopic sleeve gastrectomy: a prospective randomized trial. Surg Obes Relat Dis 11(5):997-1003

37. Fernández JI, Farías CO, Ovalle CL, Cabrera CS, de la Maza JC (2015) Transumbilical single-incision laparoscopic sleeve gastrectomy. Obes Surg 25(3):430-435

38. Frattini F, Lavazza M, Mangano A et al (2015) Indocyanine green-enhanced fluorescence in laparoscopic sleeve gastrectomy. Obes Surg 25(5):949-950

39. Gayrel X, Loureiro M, Skalli EM, Dutot C, Mercier G, Nocca D (2016) Clinical and economic evaluation of absorbable staple line buttressing in sleeve gastrectomy in high-risk patients. Obes Surg 26(8):1710-1716

40. Gerin O, Rebibo L, Dhahri A, Regimbeau JM (2015) The safety of laparoscopic sleeve gastrectomy in patients receiving chronic anticoagulation therapy: a case-matched study. Obes Surg 25(9):1686-1692

41. Gumbau V, Bruna M, Canelles E et al (2014) A prospective study on inflammatory parameters in obese patients after sleeve gastrectomy. Obes Surg 24(6):903-908

42. Hawasli A, Jacquish B, Almahmeed T et al (2015) Early effects of bougie size on sleeve gastrectomy outcome. Am J Surg 209(3):473-477

43. Hawasli A, Reyes M, Hare B et al (2016) Can morbidly obese patients with reflux be offered laparoscopic sleeve gastrectomy? A case report of 40 patients. Am J Surg 211(3):571-576

44. Hirth DA, Jones EL, Rothchild KB, Mitchell BC, Schoen JA (2015) Laparoscopic sleeve gastrectomy: long-term weight loss outcomes. Surg Obes Relat Dis 11(5):1004-1007

45. Hoogerboord M, Wiebe S, Klassen D, Ransom T, Lawlor D, Ellsmere J (2014) Laparoscopic sleeve gastrectomy: perioperative outcomes, weight loss and impact on type 2 diabetes mellitus over 2 years. Can J Surg 57(2):101-105

46. Karakoyun R, Gündüz U, Bülbüller N et al (2014) The effect of serosal suture reinforcement on burst pressure in sleeve gastrectomy specimens. Surg Laparosc Endosc Percutan Tech 24(5):424-428

47. Kasalicky M, Dolezel R, Vernerova E, Haluzik M (2014) Laparoscopic sleeve gastrectomy without over-sewing of the staple line is effective and safe. Wideochir Inne Tech Maloinwazyjne $9(1): 46-52$

48. Kruger RS, Pricolo VE, Streeter TT, Colacchio DA, Andrade UA (2014) A bariatric surgery center of excellence: operative trends and long-term outcomes. J Am Coll Surg 218(6):1163-1174

49. Kular KS, Manchanda N, Rutledge R (2014) Analysis of the five-year outcomes of sleeve gastrectomy and mini gastric bypass: a report from the Indian sub-continent. Obes Surg 24(10):1724-1728
50. Lainas P, Tranchart H, Gaillard M, Ferretti S, Donatelli G, Dagher I (2016) Prospective evaluation of routine early computed tomography scanner in laparoscopic sleeve gastrectomy. Surg Obes Relat Dis 12(8):1483-1490

51. Lakdawala M, Agarwal A, Dhar S, Dhulla N, Remedios C, Bhasker AG (2015) Single-incision sleeve gastrectomy versus laparoscopic sleeve gastrectomy. A 2-year comparative analysis of 600 patients. Obes Surg 25(4):607-614

52. Lemaître F, Léger P, Nedelcu M, Nocca D (2016) Laparoscopic sleeve gastrectomy in the South Pacific. Retrospective evaluation of 510 patients in a single institution. Int J Surg 30:1-6

53. Lopez J, Vilallonga R, Targarona EM et al (2014) Can LigaSure $^{\mathrm{TM}}$ be used to perform sleeve gastrectomy? - Tensile strength and histological changes. Minim Invasive Ther Allied Technol 23(3):144-151

54. Maluenda F, León J, Csendes A, Burdiles P, Giordano J, Molina M (2014) Single-incision laparoscopic sleeve gastrectomy: initial experience in 20 patients and 2-year follow-up. Eur Surg 46:32-37

55. Michalsky D, Dvorak P, Belacek J, Kasalicky M (2013) Radical resection of the pyloric antrum and its effect on gastric emptying after sleeve gastrectomy. Obes Surg 23(4):567-573

56. Mittermair R, Pratschke J, Sucher R (2013) Single-incision laparoscopic sleeve gastrectomy. Am Surg 79(4):393-397

57. Mittermair R, Sucher R, Perathoner A, Wykypiel H (2014) Routine upper gastrointestinal swallow studies after laparoscopic sleeve gastrectomy are unnecessary. Am J Surg 207(6):897-901

58. Mittermair R, Sucher R, Perathoner A (2014) Results and complications after laparoscopic sleeve gastrectomy. Surg Today 44(7):1307-1312

59. Mittermair R (2013) Transumbilical single-incision laparoscopic sleeve gastrectomy: short-term results and technical considerations. J Minim Access Surg 9(3):104-108

60. Mukherjee S, Devalia K, Rahman MG, Mannur KR (2012) Sleeve gastrectomy as a bridge to a second bariatric procedure in superobese patients-a single institution experience. Surg Obes Relat Dis 8(2):140-144

61. Musella M, Milone M, Maietta P, Bianco P, Pisapia A, Gaudioso D (2014) Laparoscopic sleeve gastrectomy: efficacy of fibrin sealant in reducing postoperative bleeding. A randomized controlled trial. Updates Surg 66(3):197-201

62. Noel P, Iannelli A, Sejor E, Schneck AS, Gugenheim J (2013) Laparoscopic sleeve gastrectomy: how I do it. Surg Laparosc Endosc Percutan Tech 23(1):e14-e16

63. Noel P, Nedelcu M, Gagner M (2016) Impact of the surgical experience on leak rate after laparoscopic sleeve gastrectomy. Obes Surg 26(8):1782-1787

64. Noun R, Chakhtoura G, Nasr M et al (2012) Laparoscopic sleeve gastrectomy for mildly obese patients (body mass index of $30<$ $35 \mathrm{~kg} / \mathrm{m} 2$ ): operative outcome and short-term results. J Obes. https://doi.org/10.1155/2012/813650

65. Noun R, Slim R, Nasr M et al (2016) Results of laparoscopic sleeve gastrectomy in 541 consecutive patients with low baseline body mass index (30-35 kg/m²). Obes Surg 26(12):2824-2828

66. Pequignot A, Dhahri A, Verhaeghe P, Desailoud R, Lalau JD, Regimbeau JM (2012) Efficiency of laparoscopic sleeve gastrectomy on metabolic syndrome disorders: two-year results. J Visc Surg 149:e350-e355

67. Pequignot A, Prevot F, Dhahri A, Rebibo L, Badaoui R, Regimbeau JM (2015) Is sleeve gastrectomy still contraindicated for patients aged $\geq 60$ years? A case-matched study with 24 months of follow-up. Surg Obes Relat Dis 11(5):1008-1013

68. Laimer E, Pratschke J, Mittermair R (2013) Significant weight loss and rapid resolution of diabetes and dyslipidemia during short-term follow-up after laparoscopic sleeve gastrectomy. Obes Surg 23(12):1966-1972 
69. Rossetti G, Fei L, Docimo L et al (2014) Is nasogastric decompression useful in prevention of leaks after laparoscopic sleeve gastrectomy? A randomized trial. J Invest Surg 27(4):234-239

70. Rossetti G, Moccia F, Marra T et al (2014) Does helicobacter pylori infection have influence on outcome of laparoscopic sleeve gastrectomy for morbid obesity? Int J Surg 12(Suppl 1):S68-S71

71. Schauer PR, Kashyap SR, Wolski K et al (2012) Bariatric surgery versus intensive medical therapy in obese patients with diabetes. N Engl J Med 366(17):1567-1576

72. Shah SS, Todkar JS, Shah PS (2014) Buttressing the staple line: a randomized comparison between staple-line reinforcement versus no reinforcement during sleeve gastrectomy. Obes Surg 24(12):2014-2020

73. Spivak H, Rubin M, Sadot E, Pollak E, Feygin A, Goitein D (2014) Laparoscopic sleeve gastrectomy using 42-French versus 32-French bougie: the first-year outcome. Obes Surg 24(7):1090-1093

74. Spivak H, Segev L, Meydan C, Yosef R, Ronen I, Heller L (2016) Achieving the "minimal scarring" concept in bariatrics by portsite relocation. Obes Surg 26(3):683-687

75. Sroka G, Milevski D, Shteinberg D, Mady H, Matter I (2015) Minimizing hemorrhagic complications in laparoscopic sleeve gastrectomy - a randomized controlled trial. Obes Surg 25(9):1577-1583

76. Stroh C, Köckerling F, Volker L et al (2016) Results of more than 11,800 sleeve gastrectomies: data analysis of the German Bariatric Surgery Registry. Ann Surg 263(5):949-955

77. Sucher R, Resch T, Mohr E et al (2014) Single-incision laparoscopic sleeve gastrectomy versus multiport laparoscopic sleeve gastrectomy: analysis of 80 cases in a single center. J Laparoendosc Adv Surg Tech A 24(2):83-88

78. Timucin Aydin M, Aras O, Karip B, Memisoglu K (2015) Staple line reinforcement methods in laparoscopic sleeve gastrectomy: comparison of burst pressures and leaks. JSLS 19(3): e2015.00040

79. Topart P, Becouarn G, Ritz P (2012) Comparative early outcomes of three laparoscopic bariatric procedures: sleeve gastrectomy, Roux-en-Y gastric bypass, and biliopancreatic diversion with duodenal switch. Surg Obes Relat Dis 8(3):250-254

80. Tsamis D, Natoudi M, Arapaki A et al (2015) Using Ligasure ${ }^{\mathrm{TM}}$ or Harmonic Ace ${ }^{\circledR}$ in laparoscopic sleeve gastrectomies? A prospective randomized study. Obes Surg 25(8):1454-1457

81. van Rutte P, Nienhuijs SW, Jakimowicz JJ, van Montfort G (2017) Identification of technical errors and hazard zones in sleeve gastrectomy using OCHRA: "OCHRA for sleeve gastrectomy”. Surg Endosc 31(2):561-566

82. van Rutte PW, Smulders JF, de Zoete JP, Nienhuijs SW (2014) Outcome of sleeve gastrectomy as a primary bariatric procedure. Br J Surg 101(6):661-668

83. Wahby M, Salama AF, Elezaby AF et al (2013) Is routine postoperative gastrografin study needed after laparoscopic sleeve gastrectomy? Experience of 712 cases. Obes Surg 23(11):1711-1717

84. Zachariah SK, Chang PC, Ooi AS, Hsin MC, Kin Wat JY, Huang CK (2013) Laparoscopic sleeve gastrectomy for morbid obesity: 5 years experience from an Asian center of excellence. Obes Surg 23(7):939-946

85. Abdelbaki TN, Sharaan M, Abdel-Baki NA, Katri K (2014) Laparoscopic gastric greater curvature plication versus laparoscopic sleeve gastrectomy: early outcome in 140 patients. Surg Obes Relat Dis 10(6):1141-1146

86. Al Hajj GN, Haddad J (2013) Preventing staple-line leak in sleeve gastrectomy: reinforcement with bovine pericardium vs oversewing. Obes Surg 23(11):1915-1921

87. Alsina E, Ruiz-Tovar J, Alpera MR et al (2014) Incidence of deep vein thrombosis and thrombosis of the portal-mesenteric axis after laparoscopic sleeve gastrectomy. J Laparoendosc Adv Surg Tech A 24(9):601-605

88. Alvarenga ES, Lo Menzo E, Szomstein S, Rosenthal RJ (2016) Safety and efficacy of 1020 consecutive laparoscopic sleeve gastrectomies performed as a primary treatment modality for morbid obesity. A single-center experience from the metabolic and bariatric surgical accreditation quality and improvement program. Surg Endosc 30(7):2673-2678

89. Barreto TW, Kemmeter PR, Paletta MP, Davis AT (2015) A comparison of a single center's experience with three staple line reinforcement techniques in 1,502 laparoscopic sleeve gastrectomy patients. Obes Surg 25(3):418-422

90. Belgaumkar AP, Carswell KA, Hughes RD et al (2016) The effect of intraoperative $\mathrm{N}$-acetylcysteine on hepatocellular injury during laparoscopic bariatric surgery. A randomised controlled trial. Obes Surg 26(6):1254-1265

91. Bhatia P, Bindal V, Singh R et al (2014) Robot-assisted sleeve gastrectomy in morbidly obese versus super obese patients. JSLS 18(3):e2014.00099

92. Boza C, Daroch D, Barros D, León F, Funke R, Crovari F (2014) Long-term outcomes of laparoscopic sleeve gastrectomy as a primary bariatric procedure. Surg Obes Relat Dis 10(6):1129-1133

93. Boza C, Salinas J, Salgado N et al (2012) Laparoscopic sleeve gastrectomy as a stand-alone procedure for morbid obesity: report of 1,000 cases and 3-year follow-up. Obes Surg 22(6):866-871

94. Cal P, Deluca L, Jakob T, Fernández E (2016) Laparoscopic sleeve gastrectomy with 27 versus $39 \mathrm{Fr}$ bougie calibration: a randomized controlled trial. Surg Endosc 30(5):1812-1815

95. Catheline JM, Fysekidis M, Dbouk R et al (2012) Weight loss after sleeve gastrectomy in super superobesity. J Obes. https:// doi.org/10.1155/2012/959260

96. Corcelles R, Boules M, Froylich D et al (2016) Laparoscopic three-port sleeve gastrectomy: a single institution case series. J Laparoendosc Adv Surg Tech A 26(5):361-365

97. Daes J, Jimenez M, Said N, Daza J, Dennis R (2012) Laparoscopic sleeve gastrectomy: symptoms of gastroesophageal reflux can be reduced by changes in surgical technique. Obes Surg 22:1874-1879

98. Daes J, Jimenez ME, Said N, Dennis R (2014) Improvement of gastroesophageal reflux symptoms after standardized laparoscopic sleeve gastrectomy. Obes Surg 24(4):536-540

99. Dakour Aridi H, Alami R, Tamim H, Shamseddine G, Fouani T, Safadi B (2016) Long-term outcomes of laparoscopic sleeve gastrectomy: a Lebanese center experience. Surg Obes Relat Dis 12(9):1689-1696

100. Dotai T, Coker AM, Antozzi L et al (2013) Transgastric largeorgan extraction: the initial human experience. Surg Endosc 27(2):394-399

101. Fridman A, Moon R, Cozacov Y et al (2013) Procedure-related morbidity in bariatric surgery: a retrospective short- and midterm follow-up of a single institution of the American College of Surgeons Bariatric Surgery Centers of Excellence. J Am Coll Surg 217(4):614-620

102. Garofalo F, Denis R, Abouzahr O, Garneau P, Pescarus R, Atlas H (2016) Fully ambulatory laparoscopic sleeve gastrectomy: 328 consecutive patients in a single tertiary bariatric center. Obes Surg 26(7):1429-1435

103. Gentileschi P, Camperchioli I, D’Ugo S, Benavoli D, Gaspari AL (2012) Staple-line reinforcement during laparoscopic sleeve gastrectomy using three different techniques: a randomized trial. Surg Endosc 26:2623-2629

104. Grueneberger JM, Karcz-Socha I, Marjanovic G et al (2014) Pylorus preserving loop duodeno-enterostomy with sleeve gastrectomy-preliminary results. BMC Surg 14:20 
105. Gunkova P, Gunka I, Zonca P, Dostalik J, Ihnat P (2015) Laparoscopic sleeve gastrectomy for morbid obesity with natural orifice specimen extraction (NOSE). Bratisl Lek Listy 116(7):422-425

106. Huang CK, Chhabra N, Goel R, Hung CM, Chang PC, Chen YS (2013) Laparoscopic adjustable gastric banded plication: a case-matched comparative study with laparoscopic sleeve gastrectomy. Obes Surg 23(8):1319-1323

107. Jakob T, Cal P, Deluca L, Fernández E (2016) Shorter than 24-h hospital stay for sleeve gastrectomy is safe and feasible. Surg Endosc 30(12):5596-5600

108. Ji Y, Ye H, Wang Y, Zhan X, Zhu J (2016) Laparoscopic plicated sleeve gastrectomy: a technical report. Obes Surg 26(1):234-237

109. Keidar A, Hazan D, Sadot E, Kashtan H, Wasserberg N (2015) The role of bariatric surgery in morbidly obese patients with inflammatory bowel disease. Surg Obes Relat Dis 11(1):132-136

110. Lee WJ, Lee KT, Ser KH, Chen JC, Tsou JJ, Lee YC (2015) Laparoscopic adjustable gastric banding (LAGB) with gastric plication: short-term results and comparison with LAGB alone and sleeve gastrectomy. Surg Obes Relat Dis 11(1):125-130

111. Lee WJ, Pok EH, Almulaifi A, Tsou JJ, Ser KH, Lee YC (2015) Medium-term results of laparoscopic sleeve gastrectomy: a matched comparison with gastric bypass. Obes Surg 25(8):1431-1438

112. Lin MY, Tavakol MM, Sarin A et al (2013) Laparoscopic sleeve gastrectomy is safe and efficacious for pretransplant candidates. Surg Obes Relat Dis 9(5):653-658

113. Moon RC, Kreimer F, Teixeira AF, Campos JM, Ferraz A, Jawad MA (2016) Morbidity rates and weight loss after Rouxen-Y gastgric bypass, sleeve gastrectomy, and adjustable gastric banding in patients older than 60 years old: which procedure to choose? Obes Surg 26(4):730-736

114. Moon RC, Stephenson D, Royall NA, Teixeira AF, Jawad MA (2016) Robot-assisted versus laparoscopic sleeve gastrectomy: learning curve, perioperative, and short-term outcomes. Obes Surg 26(10):2463-2468

115. Nimeri A, Maasher A, Salim E, Ibrahim M, Al Hadad M (2016) The use of intraoperative endoscopy may decrease postoperative stenosis in laparoscopic sleeve gastrectomy. Obes Surg 26(7):1398-1401

116. Obeidat F, Shanti H, Mismar A, Albsoul N, Al-Qudah M (2015) The magnitude of antral resection in laparoscopic sleeve gastrectomy and its relationship to excess weight loss. Obes Surg 25(10): 1928-1932

117. Paluszkiewicz R, Kalinowski P, Wróblewski T et al (2012) Prospective randomized clinical trial of laparoscopic sleeve gastrectomy versus open Roux-en-Y gastric bypass for the management of patients with morbid obesity. Wideochir Inne Tech Maloinwazyjne 7(4):225-232

118. Park JY, Kim YJ (2015) Laparoscopic gastric bypass vs sleeve gastrectomy in obese Korean patients. World J Gastroenterol 21(44):12612-12619

119. Peterli R, Borbély Y, Kern B et al (2013) Early results of the Swiss Multicentre Bypass or Sleeve Study (SM-BOSS): a prospective randomized trial comparing laparoscopic sleeve gastrectomy and Roux-en-Y gastric bypass. Ann Surg 258(5):690-694 discussion 695

120. Rogula T, Daigle C, Dua M et al (2014) Laparoscopic bariatric surgery can be performed through a single incision: a comparative study. Obes Surg 24(7):1102-1108

121. Rogula T, Khorgami Z, Bazan M et al (2015) Comparison of reinforcement techniques using suture on staple-line in sleeve gastrectomy. Obes Surg 25(11):2219-2224

122. Ruiz-Tovar J, Martínez R, Bonete JM et al (2016) Long-term weight and metabolic effects of laparoscopic sleeve gastrectomy calibrated with a 50-Fr bougie. Obes Surg 26(1):32-37
123. Ruiz-Tovar J, Muñoz JL, Gonzalez J et al (2017) Postoperative pain after laparoscopic sleeve gastrectomy: comparison of three analgesic schemes (isolated intravenous analgesia, epidural analgesia associated with intravenous analgesia and port-sites infiltration with bupivacaine associated with intravenous analgesia). Surg Endosc 31(1):231-236

124. Ruiz-Tovar J, Sola-Vera J, Miranda E et al (2014) Laparoscopic sleeve gastrectomy with endoscopic versus bougie calibration: results of a prospective study. J Laparoendosc Adv Surg Tech A 24(10):671-675

125. Ruiz-Tovar J, Zubiaga L, Diez M et al (2016) Preoperative regular diet of $900 \mathrm{kcal} /$ day vs balanced energy high-protein formula vs immunonutrition formula: effect on preoperative weight loss and postoperative pain, complications and analytical acute phase reactants after laparoscopic sleeve gastrectomy. Obes Surg 26(6):1221-1227

126. Seki Y, Kasama K, Hashimoto K (2016) Long-term outcome of laparoscopic sleeve gastrectomy in morbidly obese Japanese patients. Obes Surg 26(1):138-145

127. Serrano OK, Tannebaum JE, Cumella L et al (2016) Weight loss outcomes and complications from bariatric surgery in the super super obese. Surg Endosc 30(6):2505-2511

128. Shen D, Ye H, Wang Y, Ji Y, Zhan X, Zhu J, Li W (2013) Comparison of short-term outcomes between laparoscopic greater curvature plication and laparoscopic sleeve gastrectomy. Surg Endosc 27(8):2768-2774

129. Shimizu H, Phuong V, Maia M et al (2013) Bariatric surgery in patients with liver cirrhosis. Surg Obes Relat Dis 9(1):1-6

130. Soliman AM, Lasheen M (2015) Effect of banded laparoscopic sleeve gastrectomy on weight loss maintenance: comparative study between banded and non-banded sleeve on weight loss. Bariatr Surg Pract Patient Care 10(3):99-104

131. Sucandy I, Antanavicius G, Bonanni F Jr (2013) Outcome analysis of early laparoscopic sleeve gastrectomy experience. JSLS 17(4):602-606

132. Szewczyk T, Janczak P, Janiak A, Gaszyński T, Modzelewski B (2014) Laparoscopic sleeve gastrectomy - 7 years of own experience. Wideochir Inne Tech Maloinwazyjne 9(3):427-435

133. Thereaux J, Corigliano N, Poitou C, Oppert JM, Czernichow S, Bouillot JL (2015) Comparison of results after one year between sleeve gastrectomy and gastric bypass in patients with BMI $\geq 50 \mathrm{~kg} / \mathrm{m}^{2}$. Surg Obes Relat Dis 11(4):785-790

134. Våge V, Sande VA, Mellgren G, Laukeland C, Behme J, Andersen JR (2014) Changes in obesity-related diseases and biochemical variables after laparoscopic sleeve gastrectomy: a two-year follow-up study. BMC Surg 14:8

135. Verdi D, Prevedello L, Albanese A, Lobba A, Foletto M (2015) Laparoscopic gastric plication (LGCP) vs sleeve gastrectomy (LSG): a single institution experience. Obes Surg 25(9):1653-1657

136. Vix M, Diana M, Marx L et al (2015) Management of staple line leaks after sleeve gastrectomy in a consecutive series of 378 patients. Surg Laparosc Endosc Percutan Tech 25(1):89-93

137. Yang JJ, Wang B, Liang YK, Song ZC, Gu Y (2013) Early clinical efficacy of laparoscopic sleeve gastrectomy as a bariatric surgery for obese patients: a uni-center report in China. Biomed Environ Sci 26(7):539-545

138. Youssef T, Abdalla E, El-Alfy K, Dawoud I, Morshed M, Farid M (2016) Impact of botulinum neurotoxin pyloric injection during laparoscopic sleeve gastrectomy on postoperative gastric leak: a clinical randomized study. Obes Surg 26(3):494-504

139. Zerrweck C, Sepúlveda EM, Maydón HG et al (2014) Laparoscopic gastric bypass vs sleeve gastrectomy in the super obese patient: early outcomes of an observational study. Obes Surg 24(5):712-717 
140. Zhang Y, Zhao H, Cao Z et al (2014) A randomized clinical trial of laparoscopic Roux-en-Y gastric bypass and sleeve gastrectomy for the treatment of morbid obesity in China: a 5-year outcome. Obes Surg 24(10):1617-1624

141. Kehagias I, Spyropoulos C, Karamanakos S, Kalfarentzos F (2013) Efficacy of sleeve gastrectomy as sole procedure in patients with clinically severe obesity $\left(\mathrm{BMI} \leq 50 \mathrm{~kg} / \mathrm{m}^{2}\right)$. Surg Obes Relat Dis 9(3):363-369

142. Sdralis E, Argentou M, Mead N, Kehagias I, Alexandridis T, Kalfarentzos F (2013) A prospective randomized study comparing patients with morbid obesity submitted to sleeve gastrectomy with or without omentectomy. Obes Surg 23(7):965-971

143. Spyropoulos C, Argentou MI, Petsas T, Thomopoulos K, Kehagias I, Kalfarentzos F (2012) Management of gastrointestinal leaks after surgery for clinically severe obesity. Surg Obes Relat Dis 8(5):609-615

144. Cerci M, Bellini MI, Russo F et al (2013) Bariatric surgery in moderately obese patients: a prospective study. Gastroenterol Res Pract 1:1-10. https://doi.org/10.1155/2013/276183

145. Kassir R, Blanc P, Bruna Tibalbo LM, Breton C, Lointier P (2015) C-Reactive protein and procalcitonin for the early detection of postoperative complications after sleeve gastrectomy: preliminary study in 97 patients. Surg Endosc 29(6):1439-1444

146. Rawlins L, Rawlins MP, Brown CC, Schumacher DL (2013) Sleeve gastrectomy: 5-year outcomes of a single institution. Surg Obes Relat Dis 9(1):21-25

147. Andreas A, Adamantios M, Antonios A, Theofilos R, Christos T, Theodoros D (2015) Laparoscopic sleeve gastrectomy for morbid obesity with intra-operative endoscopy: lessons we learned after 100 consecutive patients. Obes Surg 25(7):1223-1228

148. El Chaar M, Hammoud N, Ezeji G, Claros L, Miletics M, Stoltzfus J (2015) Laparoscopic sleeve gastrectomy versus laparoscopic Roux-en-Y gastric bypass: a single center experience with 2 years follow-up. Obes Surg 25(2):254-262

149. Elli E, Gonzalez-Heredia R, Sarvepalli S, Masrur M (2015) Laparoscopic and robotic sleeve gastrectomy: short- and long-term results. Obes Surg 25(6):967-974

150. Gomberawalla A, Salamat A, Lutfi R (2014) Outcome analysis of single incision vs traditional multiport sleeve gastrectomy: a matched cohort study. Obes Surg 24(11):1870-1874

151. Iannelli A, Schneck AS, Topart P, Carles M, Hébuterne X, Gugenheim J (2013) Laparoscopic sleeve gastrectomy followed by duodenal switch in selected patients versus single-stage duodenal switch for superobesity: case-control study. Surg Obes Relat Dis 9(4):531-538

152. Luppi CR, Balagué C, Targarona EM et al (2015) Laparoscopic sleeve gastrectomy in patients over 60 years: impact of age on weight loss and co-morbidity improvement. Surg Obes Relat Dis 11(2):296-301

153. Nguyen NT, Smith BR, Reavis KM, Nguyen XM, Nguyen B, Stamos MJ (2012) Strategic laparoscopic surgery for improved cosmesis in general and bariatric surgery: analysis of initial 127 cases. J Laparoendosc Adv Surg Tech A 22(4):355-361

154. Noel P, Nedelcu M, Gagner M (2014) SPIDER ${ }^{\circledR}$ sleeve gastrectomy-a new concept in single-trocar bariatric surgery: initial experience and technical details. J Visc Surg 151(2):91-96

155. Ruscio S, Abdelgawad M, Badiali D et al (2016) Simple versus reinforced cruroplasty in patients submitted to concomitant laparoscopic sleeve gastrectomy: prospective evaluation in a bariatric center of excellence. Surg Endosc 30(6):2374-2381

156. Saul D, Stephens D, Hofstätter Rde C, Ahmed L, Langhoff E, Heimann TM (2012) Preliminary outcomes of laparoscopic sleeve gastrectomy in a Veterans Affairs medical center. Am J Surg 204(5):e1-e6
157. Schraibman V, Macedo AL, Epstein MG et al (2014) Comparison of the morbidity, weight loss, and relative costs between robotic and laparoscopic sleeve gastrectomy for the treatment of obesity in Brazil. Obes Surg 24(9):1420-1424

158. Toro JP, Patel AD, Lytle NW et al (2015) Observed variability in sleeve gastrectomy volume and compliance does not correlate to postoperative outcomes. Surg Laparosc Endosc Percutan Tech 25(4):324-330

159. Uffort E, Nease B, Canterbury T (2013) Laparoscopic sleeve gastrectomy with comparable weight loss in all obese groups: a VA hospital experience. Am Surg 79(7):739-742

160. Vidal P, Ramón JM, Goday A et al (2013) Laparoscopic gastric bypass versus laparoscopic sleeve gastrectomy as a definitive surgical procedure for morbid obesity. Mid-term results. Obes Surg 23(3):292-299

161. Yaghoubian A, Tolan A, Stabile B et al (2012) Laparoscopic Roux-en-Y gastric bypass and sleeve gastrectomy achieve comparable weight loss at 1 year. Am Surg 78(12):1325-1328

162. Young JA, Alijani A, Patil PV, Shimi SM (2014) Safety and feasibility of retrieval of intragastric balloon followed by antiobesity surgery on the same day. Surg Laparosc Endosc Percutan Tech 24(4):e137-e139

163. Chaar ME, Lundberg P, Stoltzfus J (2018) Thirty-day outcomes of sleeve gastrectomy versus Roux-en-Y gastric bypass: first report based on metabolic and bariatric surgery accreditation and quality improvement program database. Surg Obes Relat Dis 14(5):545-551

164. Inaba CS, Koh CY, Sujatha-Bhaskar S et al (2018) One-year mortality after contemporary laparoscopic bariatric surgery: an analysis of the bariatric outcomes longitudinal database. J Am Coll Surg 226(6):1166-1174

165. Peterli R, Wölnerhanssen BK, Peters T et al (2018) Effect of laparoscopic sleeve gastrectomy vs laparoscopic Rouxen-Y gastric bypass on weight loss in patients with morbid obesity: the SM-BOSS randomized clinical trial. JAMA 319(3):255-265

166. Salminen P, Helmiö M, Ovaska J et al (2018) Effect of laparoscopic sleeve gastrectomy vs laparoscopic Roux-en-Y gastric bypass on weight loss at 5 years among patients with morbid obesity: the SLEEVEPASS randomized clinical trial. JAMA 319(3):241-254

167. Alizadeh RF, Li S, Inaba C et al (2018) Risk factors for gastrointestinal leak after bariatric surgery: MBSAQIP Analysis. J Am Cull Surg 227(1):135-141

168. Kumar SB, Hamilton BC, Wood SG, Rogers SJ, Carter JT, Lin MY (2018) Is laparoscopic sleeve gastrectomy safer than laparoscopic gastric bypass? a comparison of 30-day complications using the MBSAQIP data registry. Surg Obes Relat Dis 14(3):264-269

169. Birkmeyer JD, Finks JF, O'Reilly A et al (2013) Surgical skill and complication rates after bariatric surgery. N Engl J Med 369(15):1434-1442

170. Hany M, Ibrahim M (2018) Comparison between stable line reinforcement by barbed suture and non-reinforcement in sleeve gastrectomy: a randomized prospective controlled study. Obes Surg. 28:2157-2164

171. Durmush EK, Ermerak G, Durmush D (2014) Short-term outcomes of sleeve gastrectomy for morbid obesity: does staple line reinforcement matter? Obes Surg 24(7):1109-1116

172. Nedelcu M, Manos T, Gagner M, Eddbali I, Ahmed A, Noel P (2017) Cost analysis of leak after sleeve gastrectomy. Surg Endosc 31(11):4446-4450

173. Baker RS, Foote J, Kemmeter P, Brady R, Vroegop T, Serveld M (2004) The science of stapling and leaks. Obes Surg 14(10):1290-1298 
174. Elariny H, Gonzalez H, Wang B (2005) Tissue thickness of human stomach measured on excised gastric specimens from obese patients. Surg Technol Int 14:119-124

175. Nguyen NT, Longoria M, Welbourne S, Sabio A, Wilson SE (2005) Glycolide copolymer staple-line reinforcement reduces staple site bleeding during laparoscopic gastric bypass: a prospective randomized trial. Arch Surg 140(8):773-778

176. Rawlins L, Rawlins M, Teel D (2014) Human tissue thickness measurements from excised sleeve gastrectomy specimens. Surg Endosc. 28(3):811-814 Erratum in Surg Endosc 2014;28(3):815

177. van Rutte PW, Naagen BJ, Spek M, Jakimowicz JJ, Nienhuijs SW (2015) Gastric wall thickness in sleeve gastrectomy patients: thickness variation of the gastric wall. Surg Technol Int $27: 123-128$
178. Huang R, Gagner M (2015) A thickness calibration device is needed to determine staple height and avoid leaks in laparoscopic sleeve gastrectomy. Obes Surg 25:2360-2367

179. Barski K, Binda A, Kudlicka E, Jaworski P, Tarnowski W (2018) Gastric wall thickness and stapling in laparoscopic sleeve gastrectomy-a literature review. Wideochir Inne Tech Maloinwazyjne 13(1):122-127

Publisher's Note Springer Nature remains neutral with regard to jurisdictional claims in published maps and institutional affiliations. 